\title{
Employer-of-choice branding for knowledge workers
}

\author{
M.M. Sutherland*, D.G. Torricelli and R.F. Karg \\ Wits Business School, University of the Witwatersrand, \\ PO Box 98, Wits 2050, Republic of South Africa \\ sutherland.m@wbs.wits.ac.za
}

Received October 2002

\begin{abstract}
Attracting knowledge workers is recognised as a critical success factor by organisations. In order to succeed in the war for talent many organisations realise they need to brand themselves as employers of choice. This research established the factors knowledge workers regard as important organisational attributes when seeking an employer and what communication channels signal these attributes to knowledge workers.
\end{abstract}

This was a two-phase study involving 274 knowledge workers. Qualitative research identified the organisational attributes desired and the communication channels used. Quantitative research using Factor Analysis, Kruskal Wallis and Mann Whitney U tests established the underlying factors, their order of importance and the significant differences in the target market segmentation.

The findings show 11 underlying factors, with career growth and challenging work opportunities being the most desired attributes. Word of mouth and/or current employees are the most used communication channels. Differences in the target market were noted by gender, age and cultural groupings. Recommendations are offered for organisations seeking to become employers of choice.

*To whom all correspondence should be addressed.

\section{Introduction}

It is often said that a company is only as good as its people and that talented employees are the driving force behind every successful company. Knowledge workers are seen as a source of competitive advantage in a world in which most processes and systems have been standardised across industry participants (Templer \& Cawsey, 1999). Tulgan (2001) defines knowledge workers as any employee that uses knowledge to add value to a business process. Rifkin (2000) defines them as 'the creators, manipulators and purveyors of the stream of information that makes up the postindustrial, postservice global economy'. A company's ability to attract and retain knowledge workers is therefore a critical component in determining its present and future success. Attracting and retaining intellectual capital $-\mathrm{a}$ cadre of highly skilled, independent, internationally marketable and mobile individuals - is a critical feature of globalisation (Paul, 2000). To remain competitive, companies need to ensure that they position themselves as an employer of choice. Knowing what knowledge workers are looking for when selecting an employer, is a first step to ensuring that a company strives to satisfy these needs so as to attain the status of an employer of choice.

According to a study conducted in the United States by The Conference Board (2001), companies are using the techniques of corporate brand building in order to attract and retain good employees. Cappelli (2001:140) describes today's labour market as being a true market. He states that,
'The hiring process, has become nearly indistinguishable from the marketing process'.

Employer of choice branding refers to the process of identifying and creating a company brand message. The employer branding philosophy therefore requires the application of marketing principles, to the company's recruitment and retention strategy. Kotler (1997) refers to three phases in the marketing process. These are: the segmentation of the market, the selection of the appropriate market target and the development of the offers value positioning, to appeal to that target market; in this case, knowledge workers. A key part of segmentation is carrying out research to identify the target market's behaviour and what appeals to it. It is also equally important to use the correct type of channels to convey the brand message. Robbins (1998) discusses a hierarchy of channel richness that has specific suitability in different circumstances. Knowledge workers are often in a position to choose to which organisations they will sell their services and are likely to be sensitive to particular channels of communicating a brand image.

\section{Literature review}

\section{The talent war}

Frost (2001) discusses the increased difficulty in securing management in South Africa where the brain drain is aggravating the situation. A seller's market exists for top performing skilled knowledge workers worldwide. As a 
result companies are discovering that not only is it becoming increasingly difficult to recruit top talent, but that they are running the constant risk of loosing the ones they have to competitors. 'Recruiting smart, capable people is the single most important job in corporate America today. The most important, that is, after keeping smart capable people out of the hands of other body snatchers... Businesses will live and die based on their ability to attract the right talent for the job' (Leonard, 2000).

Butler and Waldroop (1999) noted that the single most important thing on the minds of new MBA's is not money, but whether a position will move their long-term careers in a chosen direction. However, companies find themselves in a dilemma, because as they grow and train their employees, they make them more marketable. Not providing skilled employees with opportunities to grow and advance, however will simply result in them leaving.

\section{Employer branding}

A brand name is 'essentially a seller's promise to consistently deliver a specific set of features, benefits and services to the buyers' (Kotler, 1997:443). While much has been written about traditional marketing approaches to selling the organisation's products or services and even the organisation itself as a brand, little writing exists on the topic of employer branding. Little in the way of empirical studies appears to have been done on what knowledge workers look for in organisations.

'Job conditions today need to be approached in much the same way as prospective customers: carefully identified and targeted, attracted to the company and its brand and then sold on the job' (Cappelli, 2001:140). Branham (2000:18) sums up employer branding as, 'Applying traditional marketing principles to achieving the status of Employer of Choice.... The process of placing an image of being, a great place to work, in the mind of the targeted candidate pool'. Employer branding therefore entails differentiating the company's brand message so as to appeal to the current and future workforce, in a manner that sets it apart from competitors, competing for the same talent pool. As knowledge workers determine what they want, they'll seek employers that offer that special and unique combination that suits their particular needs (Herman \& Gioia, 2000). In competitive consumer markets, brand and reputation determine success or failure. Cappelli (2001) implies that the same is now true in labour markets.

Kotler (1997) refers to a brand conveying up to six levels of meaning. These are: attributes, benefits, values, culture, personality and the kind of user. The stronger the brand message appeals to top performers, the more these individuals will want to work for the company. Employer branding is therefore a key strategy to attracting and retaining the best.

Employer branding uses aspects of corporate identity and reputation specifically to achieve the multiple objectives of human resources management. The research conducted by The Conference Board (2001) showed that some companies used dedicated employer branding efforts to align employees with organisational vision and values, while others pursue the goal as part of a broader corporate branding strategy. The trend to develop a separate employer brand is however increasing, according to The Conference Board (2001) who defines the two as follows:

- Employer branding encompasses the firms value systems, policies and behaviours, towards the objective of attracting, motivating and retaining the firm's current and potential employees.

- A corporate brand embodies company values and a promise of value to be delivered. It may be used to differentiate your company from your competitors, based on your strengths, your corporate culture, corporate style and future direction.

Corporate branding is more complex than product or service branding. The management of stakeholder perceptions and the communication of the brand message requires a longerterm and a more holistic approach to the way in which the organisation communicates with stakeholders (Bernstein, 1986). The current view of corporate branding is that the corporate identity is more complex in that corporate culture and behaviour are also part of the corporate identity mix (Schmidt \& Ludlow, 1995). Consumers of the organisational brand are different from those of the product brands, and employees are an integral part of the corporate brand-building effort (King, 1991). Employer branding is therefore a new approach in order to gain an edge in the war for talent.

\section{An employer of choice}

Sullivan (1998:1) refers to an employer of choice as being, 'A company that because of it's status and reputation is, always the first choice (or at least on the short list) of world class candidates'. Employers of Choice are those organisations that outperform their competition to attract, develop, and retain people with business-required talent. They achieve this recognition through innovative and compelling human resource programs that benefit both employees and their organisations alike (Copeland, 2000).

An employer of choice is therefore an organisation which top talent aspires to work for as a result of its reputation and employer brand message, both of which are tailored to appeal to the target audience. Herman and Gioia (2000) refer to the ideal of being an employer of choice, as a means of shifting the objective from just getting people to apply, to choosing the best of the best. Employer branding concentrates on communicating that image to prospective and current employees.

\section{Criteria to attract knowledge workers}

Little empirical research exists on the criteria knowledge workers regard as important in their selection of an organisation as an employer of choice.

Lopus and Murray (2001) state what employees regard as the best practices of organisations as: a high degree of employee involvement; performance management based on 
the principle of merit; a potential for growth in professional competence; a potential for job advancement with the associated rewards; and a management that acts with integrity and caring.

Herman \& Giola (2000) identify eight factors that knowledge workers look at in evaluating an organisation as an employer of choice. These are, in no specific order of importance: company reputation; company culture; enlightened leadership; treatment of people; opportunity for career growth and opportunity; meaningful work; and compensation and benefits.

Further criteria suggested by Branham (2000) for organisations wanting to select high-performing employees are: the offer of opportunities for rapid advancement; a high risk-reward profile; and an exciting challenge and improved lifestyle benefits. Simons (2000) identifies issues such as a motivational work environment, a compatible work culture, and an appropriate work/life balance as being more important than money for talented workers.

The literature overwhelmingly suggests that a key characteristic of an employer of choice is that it provides personal and career growth opportunities. Tulgan (2001) notes that his research shows that people are preoccupied with growth opportunities. Herman and Gioia (2000) defines a key characteristic of an employer of choice to be an organisation which provides plenty of opportunities for people to learn, grow and reach their full potential. A 1999 study by the Roffey Park Management Institute noted that the main reason for staying in a job was challenge, which won out over money (Johnson, 2000). 'Employees don't come to work just to do a job. They expect development and an organisation that will pay them to hone their skills' (Johnson, 2000).

Herman and Gioia (2000) regard a good internal communication system as being a common characteristic of employers of choice. Employer branding needs to communicate its strategy both inside and outside the company. The internal audience will form their impressions predominantly from internal conditions and the external audience from communication and word of mouth. The internal audience therefore has the potential to become brand ambassadors (Ludlow, 1999). Effective communication is regarded as critical but how this is to be achieved is not specified in the literature.

Many of the criteria listed are anecdotal. Surveys that have been conducted draw their results from potential employees who are not necessarily knowledge workers. Other writings discuss criteria but not in the context of attracting employees to organisations but rather as general criteria around attraction and retention of knowledge workers. It is apparent that more work needs to be done to gather empirical data on this topic to validate the criteria that have been outlined in the writings.

\section{The marketing process}

Kotler (1997) identifies the strategic marketing process as comprising of the following three phases:

- Market segmentation

- Market targeting

- Market positioning.

A market segment consists of a large identifiable group within a market (Kotler, 1997). Segment marketing allows the company to fine-tune its message, so as to appeal to the particular segment in the market. This is in contrast to mass marketing, which results in a general marketing message, which tries to appeal to the entire market. The market segmentation procedure comprises a survey, analysis and a profiling stage. This enables the researcher to differentiate the segments by means of characteristics, which appeal to the different segments. Kotler (1997) lists the following bases for segmentation: Geographic, demographic, psychographic and behavioural. Robbins (1998) mentions the role cultural values and lifestyle preferences play in influencing one's perceptions of the work environment. With regard to South African knowledge workers it was felt that the variables of age, gender and cultural grouping may provide the basis for a market segmentation.

Once the organisation has identified the market segments, it needs to determine which of the segments it wants to and can effectively target. Kotler (1997) recommends that an organisation should only enter market segments in which it can offer superior value.

Market positioning involves identifying possible positioning strategies for the target segments, the company wants to enter into. Once the company has developed a positioning strategy, it must communicate the chosen positioning concept via selected communication channels. Communication plays a critical role in branding efforts and in enhancing the organisation's reputation (Bickerton, 2000). Cornelissen (2000) advances a model of message sources for corporate communication. These are:

- $\quad$ corporate communication - symbolism, communication and behaviour;

- $\quad$ other communication - media;

- interpersonal - word of mouth about brand or organisation; and

- $\quad$ intrapersonal - previous experiences and memories.

This study looks to assist companies to tailor their employer-branding message to the labour market segment of knowledge workers.

\section{Conclusion}

In the information age, talent is critical to value creation and great talent has a much bigger impact than even average talent (Harvard Business Update, 2001). The challenge therefore for the present and the future is how to attract this talent. The first step is understanding what this talent values and whether different demographic groups, that make up this talent pool, value different company attributes. Hannek 
Frese of Zurich Financial Services notes that, 'If we want to attract young talent, we need to fully understand their values.... With everyone going for a similar profile, the winners will be those who are able to differentiate themselves' (Johnson, 2000:153). Branham (2000:18) suggests that companies need to 'apply traditional marketing principles to achieve the status of Employer of Choice'. No empirical evidence of the criteria used by knowledge workers in selecting employers of choice was found in the literature.

\section{Research questions}

Three research questions informed these studies:

Research question 1

What communication channels are used by knowledge workers to identify employers of choice?

Research question 2

What are the underlying attributes that knowledge workers use to identify employers of choice?

Research question 3

Are there significant differences in the organisational attributes desired by knowledge workers of different age, gender and cultural groupings? Thus can the target market be segmented?

\section{Methodology}

The literature review revealed a dearth of empirical evidence of the criteria used by knowledge workers to evaluate employers of choice. This was a two-phase exploratory study; firstly to identify the criteria used and how these criteria are detected. Secondly to quantify the perceived attributes of employers of choice in order to rank order them as well as to discover the underlying structure of the criteria.

\section{Population and sample}

In both studies the population were students doing either postgraduate business management diplomas or Masters degrees at a university business school. They were thought to represent knowledge workers as they represent achievement orientated degreed individuals. Despres and Hiltrop (1995) identify knowledge workers as having loyalty to their professions and peers, as opposed to any organisation, and advancing their careers though external study instead of internal organisational training and development programmes. The samples were convenience samples (Nel, Radel \& Loubser 1990). This is a useful method to determine ideas and insights during exploratory research but does not claim to statistically represent the entire population. In the first phase there were 135 respondents and in the second 139 respondents. A total sample of 274 . In both studies the bulk of the respondents (76\%) fell into the 26 to 35 -age category.

\section{Phase 1}

This was qualitative research aimed at identifying the criteria used to identify employers of choice as well as the communication channels used to identify the attributes of potential employers. The questionnaire consisted of openended questions asking what attributes are displayed by the company they would most like to join and how they know that company has those attributes. Open-ended questions are used when the researcher does not have a clear idea of the respondents' frame of reference particularly in exploratory research (Cooper \& Emory, 1995). The respondents gave 411 statements identifying desirable employers. These were content analysed into 29 attributes. Fifteen of those attributes accounted for $80 \%$ of the total. The 6 communication channels identified are discussed below.

\section{Phase 2}

The questionnaire used to gather the quantitative data consisted of a list of thirty-three attributes. The 135 respondents rated the importance that each attribute plays in their selection of their ideal employer on a five point Likert scale. The 29 attributes formulated in Phase 1 were extended to include the following:

- benefits was split into pay, fringe benefits and profit sharing / share options.

- ability to dress casually and know existing staff, were added.

The questionnaire was pre-tested and certain attributes were then re-worded to improve clarity. The attributes were presented alphabetically.

\section{Data analysis}

The ordinal data for the four age and race categories, was subjected to the Kruskal-Wallis statistical test and the data for the two gender category was subjected to the MannWhitney $U$ test. The tests were run with a significance level of 0,05 . This was in order to determine which attributes, were rated significantly differently, by each group within the age, race and gender demographic categories in order to identify variables for a market segmentation. A Correspondence Analysis was carried out to convert the ordinal data into interval data via rescaling the Euclidean distance between the scale points calculated from the coordinates on the two principal axes of the correspondence analysis (Bendixen \& Sandler, 1995) to enable a Factor Analysis to be performed. The following table represents the conversion of the Likert scale to the rescaled data:

\section{Table 1: Conversion of Likert scale rating}

\begin{tabular}{l|l|c}
\hline \multicolumn{1}{c|}{ Likert } & \multicolumn{1}{|c}{ Verbal scale } & rescaled \\
\hline 1 & Not at all important & 1 \\
\hline 2 & Somewhat important & 2,64 \\
\hline 3 & Moderately important & 3,25 \\
\hline 4 & Very important & 3,95 \\
\hline 5 & Highly important & 5,00 \\
\hline
\end{tabular}

A Principle Component Factor Analysis using orthogonal rotation was carried out on the rescaled data to determine the underlying structure of the attributes of employers of 
choice to a more manageable set of variables (Cooper \& Emory, 1995). Eleven factors all having an eigenvalue greater than 1 emerged. The 11 factor solution accounted for $65.5 \%$ of the variance in the data. All factor loadings greater than 0.5 were included in the relevant factor.

\section{Research findings}

\section{Communication channels}

The respondents gave 250 open-ended responses in Phase 1 of the study on the channels they perceived as having conveyed the organisational attributes of employers of choice. The answers were content analysed into the six channels listed in Table 2.

\section{Table 2: Ranked list of communication channels}

\begin{tabular}{l|l|c}
\hline Rank & \multicolumn{1}{|c|}{ Channel } & Mentions \\
\hline 1 & CURRENT EMPLOYEES & 54 \\
\hline 2 & WORD OF MOUTH & 52 \\
\hline 3 & MEDIA & 42 \\
\hline 4 & $\begin{array}{l}\text { FIRST-HAND EXPERIENCE e.g. as } \\
\text { customer or supplier }\end{array}$ & 41 \\
\hline 5 & BRANDING & 14 \\
\hline 6 & INTERNET & 11 \\
\hline
\end{tabular}

A critical part of the employer brand communication strategy must therefore be directed at present employees. Kennedy (1977) mentions that current employees will strongly influence the word of mouth reputation of an employer of choice. King (1991) and Charland (2000) both state that organisations that do not brand themselves internally as employers of choice are unlikely to succeed in branding themselves as such with the external labour market. Word of mouth channels are equally important. Cable, Aiman-Smith, Mulvey and Edwards (2000) suggest that information about organisations gathered by word of mouth has a strong influence on consumer's product judgement where extensive information is difficult to obtain.

\section{Attributes of employers of choice}

To reduce the 33 attributes into a smaller number of factors that determine employers of choice a factor analysis was performed. It revealed 11 underlying factors. Table 3 gives the rank ordered factors based on the factor means (5 representing highly important, 1 of no importance).

The research conducted confirms that knowledge workers rate career growth opportunities and a challenging work environment, as the most important attribute of an employer of choice. This confirms Herman and Gioia's (2000) findings that growth, meaningful work, involvement and the opportunity to make a difference, are more important today than money, to most knowledge workers. This study further confirms a Roffey Park (an UK management institute) study conducted in 1999, which found that the main reason for staying with a company was challenge, not money (Johnson, 2000).

Table 3: Employers of choice factors ranked in order of importance, over all demographic categories

\begin{tabular}{l|l|c}
\hline Ranking & \multicolumn{1}{|c}{ Factor } & Mean \\
\hline 1 & $\begin{array}{l}\text { Corporate culture of career growth and } \\
\text { challenging work }\end{array}$ & 4,46 \\
\hline 2 & $\begin{array}{l}\text { Personal training and development } \\
\text { opportunities }\end{array}$ & 4,32 \\
\hline 3 & $\begin{array}{l}\text { Pay, including it being linked to performance, } \\
\text { profit sharing }\end{array}$ & 4,23 \\
\hline 4 & $\begin{array}{l}\text { Global, innovative company based on good } \\
\text { products }\end{array}$ & 3,96 \\
\hline 5 & $\begin{array}{l}\text { Large organisation offering job rotation and } \\
\text { diversity }\end{array}$ & 3,86 \\
\hline 6 & Successful company based on strong products & 3,84 \\
\hline 7 & $\begin{array}{l}\text { Challenging work, in a non hierarchical } \\
\text { company (excluding job security and/or large } \\
\text { organisation) }\end{array}$ & 3,80 \\
\hline 8 & Like the work and the industry & 3,78 \\
\hline 9 & $\begin{array}{l}\text { Value based organisation valuing employees, } \\
\text { cultural diversity, social responsibility, access } \\
\text { to resources }\end{array}$ & 3,77 \\
\hline 10 & $\begin{array}{l}\text { Benefits such as fringe benefits, status and } \\
\text { work experience }\end{array}$ & 3,64 \\
\hline 11 & $\begin{array}{l}\text { Comfort in knowing existing staff, small } \\
\text { organisation, casual dress, comfortable } \\
\text { working environment }\end{array}$ & 2,70 \\
\hline
\end{tabular}

Training and development were rated as being the second most important attribute. This confirms the literature available, which suggests that a key characteristic of an employer of choice is that it provides personal career growth opportunities. This also confirms a statement by Johnson (2000) that in today's world, reward is increasingly based not just on money, but on a balanced lifestyle, with a priority based on challenge and personal development. Further the data highlights that the key question for top performing knowledge workers is not whether personal development is more important than their career, but whether these can be achieved in tandem (Johnson, 2000). There is no doubt that South African knowledge workers, like their overseas counterparts, seek to broaden and shape their skills in order to make them even more marketable and employable. They understand that the only source of a persons career security is their own ability, in this high tech, high speed, knowledge based, superfluid economy (Tulgan, 2001).

A link between good pay and performance was rated as the third most important factor. Tulgan (2001:82) advocates that 'pay for performance contracts will be the natural culmination of the free market for talent and therefore, the norm of employment in the new economy'. Branham (2000:8) notes that, 'When it comes to pay most talented people seem to want something more - something most companies don't give - the assurance that the better they perform, the more they can earn....'

The first three factors relate strongly with the findings of Kinnear and Sutherland (2000) on determinants of 
organisational commitment among knowledge workers. Hence these factors are shown to be important in both attraction and retention in the war for talent. The fourth and sixth factors relate to corporate image and thus show the importance of the overlap between corporate and employer branding as discussed by The Conference Board (2001).

Comfort in knowing existing staff, small organizations and the ability to dress casually and a comfortable work environment were rated the least important attribute in the factor analysis. A large gap exists between the means of these bottom attributes and the rest, demonstrating their insignificance. This confirms a survey reported by Colvin (2000).

\section{Market segmentation}

The original 33 variables were subjected to inferential testing to discover if there were significant differences in the various segments in the target market. The tests were carried out on all 33 variables in order to detect differences that might be hidden in the factor analysis process.

\section{Age}

The top 5 attributes per age category are shown below.

Table 4: The top five attributes for the four age categories

\begin{tabular}{|c|c|c|}
\hline Rank & $\begin{array}{c}\text { Less than } 26 \text { years of } \\
\text { age }(n=10)\end{array}$ & 26 to 30 years of age $(n=61)$ \\
\hline 1 & $\begin{array}{l}\text { Career growth } \\
\text { opportunities }\end{array}$ & Career growth opportunities \\
\hline 2 & $\begin{array}{l}\text { Challenging work } \\
\text { environment }\end{array}$ & Challenging work environment \\
\hline 3 & $\begin{array}{l}\text { Pay / Performance } \\
\text { link }\end{array}$ & Like the work \\
\hline 4 & Personal development & Personal development \\
\hline 5 & Pay & Innovative $\&$ dynamic employer \\
\hline Rank & $\begin{array}{c}31 \text { to } 35 \text { years of age } \\
(n=50)\end{array}$ & $\begin{array}{c}\text { Greater than } 36 \text { years of age } \\
(n=17)\end{array}$ \\
\hline 1 & $\begin{array}{l}\text { Career growth } \\
\text { opportunities }\end{array}$ & Challenging work environment \\
\hline 2 & $\begin{array}{l}\text { Challenging work } \\
\text { environment }\end{array}$ & $\begin{array}{l}\text { Employees valued ( Interest in } \\
\text { Employees) }\end{array}$ \\
\hline 3 & Personal development & Career growth opportunities \\
\hline 4 & $\begin{array}{l}\text { Pay / Performance } \\
\text { link }\end{array}$ & Personal development \\
\hline 5 & Like the work & Like the work \\
\hline
\end{tabular}

Table 5 shows that out of the thirty-three attributes, a series of Kruskal Wallis tests (at alpha $=0,05$ ) showed there was only one attribute, which the age groups felt significantly different about: the younger the group the more important they rated the importance of the employer being a global player. This might either be linked to the desire to get international exposure or a wish to emigrate.

\section{Gender}

The top six attributes for the two gender categories are shown in Table 6. Both men and women rated career growth opportunities and a challenging work environment as their top attributes. Men were more concerned about issues relating to pay as opposed to women respondents who viewed development opportunities as more important. This is confirmed in Table 7, which shows the results obtained by applying the Mann-Whitney U statistical test to the data, to determine the significant differences between the two groups. Out of thirty-three attributes there were four attributes about which the two gender categories felt significantly different.

Table 5: The significant differences between the four age categories

\begin{tabular}{l|c|c|c|c}
\hline Attribute Description & \multicolumn{4}{|l}{ Mean* } \\
\hline & $<26$ & $26-30$ & $31-35$ & $36<$ \\
\hline Global player & 4,10 & 4,07 & 3,76 & 3,53 \\
\hline \multicolumn{6}{c}{$* 5$ being highly important }
\end{tabular}

Table 6: The top six attributes for the two gender categories

\begin{tabular}{c|l|l}
\hline Rank & \multicolumn{1}{|c}{ Male $(\mathbf{n = 9 9 )}$} & \multicolumn{1}{c}{ Female $(\mathbf{n = 3 9 )}$} \\
\hline $\mathbf{1}$ & $\begin{array}{l}\text { Career growth } \\
\text { opportunities }\end{array}$ & Career growth opportunities \\
\hline $\mathbf{2}$ & $\begin{array}{l}\text { Challenging work } \\
\text { environment }\end{array}$ & Challenging work environment \\
\hline $\mathbf{3}$ & Pay / Performance link & Like the work \\
\hline $\mathbf{4}$ & Personal development & Ongoing training opportunities \\
\hline $\mathbf{5}$ & Like the work & Personal development \\
\hline $\mathbf{6}$ & Pay & $\begin{array}{l}\text { Innovative \& Dynamic } \\
\text { Employer }\end{array}$ \\
\hline
\end{tabular}

Table 7: The significant differences between the two gender categories

\begin{tabular}{l|c|c}
\hline \multicolumn{1}{c|}{ Attribute Description } & \multicolumn{2}{c}{ Mean } \\
\hline & Male & Female \\
\hline Pay / Performance & 4,54 & 4,13 \\
\hline Pay & 4,41 & 4,10 \\
\hline Job diversity / job rotation & 3,54 & 4,03 \\
\hline Ongoing training opportunities & 4,11 & 4,41 \\
\hline
\end{tabular}

This confirms Branham (2000) recommendations that companies should provide job rotations as a means to prepare as many women and other minorities, as possible for higher-level positions.

\section{Race}

The top five attributes across the four race categories are detailed in Table 8. Career growth opportunities, was once again ranked as the top attribute across all the race categories. All the top five attributes for black respondents relate to improving their skills. White respondents show an interest in improving their skills but are trying to find a balance between pay and enjoying their work. 
Table 8: The top five attributes for the four categories

\begin{tabular}{c|l|l}
\hline Rank & \multicolumn{1}{|c|}{ Black (n=25) } & \multicolumn{1}{c}{ White (n=89) } \\
\hline $\mathbf{1}$ & $\begin{array}{l}\text { Career growth } \\
\text { opportunities }\end{array}$ & Career growth opportunities \\
\hline $\mathbf{2}$ & $\begin{array}{l}\text { Challenging work } \\
\text { environment }\end{array}$ & Challenging work environment \\
\hline $\mathbf{3}$ & Personal development & Like the work \\
\hline $\mathbf{4}$ & Access to resources & Pay / Performance link \\
\hline $\mathbf{5}$ & $\begin{array}{l}\text { Ongoing training } \\
\text { opportunities }\end{array}$ & $\begin{array}{l}\text { Innovative \& dynamic } \\
\text { employer }\end{array}$ \\
\hline $\mathbf{R a n k}$ & \multicolumn{1}{|c}{ Asian (n=18) } & \multicolumn{1}{c}{ Coloured (n=4) } \\
\hline $\mathbf{1}$ & $\begin{array}{l}\text { Career growth } \\
\text { opportunities }\end{array}$ & Career growth opportunities \\
\hline $\mathbf{2}$ & Pay / Performance link & Challenging work environment \\
\hline $\mathbf{3}$ & $\begin{array}{l}\text { Personal development } \\
\text { Employers valued (Interest in } \\
\text { Employees) }\end{array}$ \\
\hline $\mathbf{4}$ & $\begin{array}{l}\text { Challenging work } \\
\text { environment }\end{array}$ & Personal development \\
\hline $\mathbf{5}$ & Like the work & Gain work experience \\
\hline
\end{tabular}

Table 9: The ranked significant differences between the four race categories

\begin{tabular}{l|c|c|c|c|c}
\hline $\begin{array}{c}\text { Attribute } \\
\text { Description }\end{array}$ & \multicolumn{4}{c|}{ Mean } & Difference \\
\hline & Black & White & Asian & Colour. & $\begin{array}{c}\text { In mean } \\
\text { between } \\
\text { Whites \& } \\
\text { Blacks }\end{array}$ \\
\hline $\begin{array}{l}\text { Cultural } \\
\text { diversity of } \\
\text { staff }\end{array}$ & 4,04 & 2,84 & 3,83 & 4,17 & 1,20 \\
\hline $\begin{array}{l}\text { Non- } \\
\text { hierarchical } \\
\text { structure }\end{array}$ & 4,00 & 3,16 & 3,72 & 4,17 & 0,84 \\
\hline $\begin{array}{l}\text { Access to } \\
\text { resources }\end{array}$ & 4,56 & 3,93 & 4,39 & 4,50 & 0,63 \\
\hline $\begin{array}{l}\text { Physical work } \\
\text { environment }\end{array}$ & 2,67 & 3,29 & 3,44 & 3,67 & 0,62 \\
\hline Vocation & 2,52 & 3,07 & 3,33 & 3,67 & 0,55 \\
\hline $\begin{array}{l}\text { Socially } \\
\text { responsible } \\
\text { company }\end{array}$ & 3,36 & 2,93 & 3,44 & 4,17 & 0,43 \\
\hline $\begin{array}{l}\text { Company } \\
\text { reputation / } \\
\text { image }\end{array}$ & 4,16 & 3,73 & 3,94 & 4,30 & 0,43 \\
\hline $\begin{array}{l}\text { Ongoing } \\
\text { training } \\
\text { opportunities }\end{array}$ & 4,52 & 4,11 & 4,06 & 4,50 & 0,41 \\
\hline $\begin{array}{l}\text { Personal } \\
\text { development }\end{array}$ & 4,60 & 4,29 & 4,72 & 4,83 & 0,31 \\
\hline $\begin{array}{l}\text { Fringe } \\
\text { benefits }\end{array}$ & 3,88 & 3,58 & 4,11 & 4,33 & 0,30 \\
\hline
\end{tabular}

Table 9 shows the results of applying the Kruskal Wallis test to the data. Out of the thirty-three attributes, ten attributes were rated significantly different between the four race groups. This indicates that the most likely means of segmenting this target market is across demographic race categories, as it is across these segments that the most significant differences exist. This study confirms Robbin's (1998:14) observation that, 'Employees don't set aside their cultural values and lifestyles preferences when they come to work. Managers will need to shift their philosophy from treating everyone alike to recognising differences and responding to those differences in ways that will ensure employer retention'.

Out of the ten attributes, which proved significantly different between the groups, it was felt that emphasising the cultural diversity of the organisation, the nonhierarchical structure and the access to resources which the employer provides, in the employer brand message is the most likely means to attract affirmative action candidates.

\section{Conclusions}

This report confirms that career growth opportunities and a challenging work environment are the most important attributes of an employer of choice, over all demographic categories. This is in accordance with the literature, which predominantly comes from America and Europe. South African knowledge workers, like their overseas counterparts understand the importance of continual growth, in order to ensure future employability. This therefore becomes the basic underlying message that any employer brand must convey. Issues relating to pay proved to be the second most important attribute. Johnson's (2001:34) statement that, 'I'll work hard for you as long as you pay me the going rate, challenge me and keep my skills ahead of the marketplace; fail to do that and I am out of here', holds true for South African knowledge workers. All demographic groups rated a link between pay and performance to be more important than a straight pay package and should form a second critical part of a knowledge workers reward package.

This research gained an understanding of what knowledge workers view as the most important attributes of their ideal employer. It is therefore hoped that the findings of this research, will both contribute to and stimulate discussion around the 'employer branding' and 'employer of choice' concepts.

\section{References}

Bendixen, M.T. \& Sandler, M. 1995. 'Converting verbal scales to interval scales using correspondence analysis', Management Dynamics: Contemporary Research, 14(1):3250.

Bernstein, D. 1986. Company image and reality: A critique of corporate communications. Eastbourne: Holt, Reinhart \& Winston.

Bickerton, D. 2000. 'Corporate reputation versus corporate branding: The realist debate', Corporate Communications, 5(1): 42-48.

Branham, L. 2000. Keeping the People Who Keep You in Business. New York: AMACOM.

Butler, T. \& Waldroop, J. 1999. 'Job sculpting, the art of retaining your best people', Harvard Business Review, Sept/Oct: 144-150.

Cable, J., Aiman-Smith, L., Mulvey, P. \& Edwards, J.R. 2000. 'The sources and accuracy of applicants' beliefs about 
organizational culture', Academy of Management Journal, 44(6):1076-1085

Cappelli, P. 2001. 'Making the most of on-line recruiting', Harvard Business Review, March 2001:139-148.

Charland, B. 2000. 'A new prescription for internal branding: The role of employees in brand definition and promotion'. [online] URL:

http://www.golinharris.com/resources/article_vol1_ charland. asp (accessed 10 June 2001).

Colvin, G. 2000. 'Corporate America: stop being clothes minded', Fortune Magazine, 142(6):26.

Copeland, J. 2000. 'Attracting and keeping the best people', [online] URL:

http://www.accounting. pronet.com/x27635 xml] (accessed 12 June 2001).

Cornelissen, J. 2000. 'Corporate image: An audience centred model', Corporate Communications, 5(2):119 125

Cooper, D.R. \& Emory, C.W. 1995. Business research methods. Chicago. Irwin.

Depres, C. \& Hiltrop, J.M. 1995. 'Human resource management in the knowledge age: Current practice and perspectives on the future', Employee Relations, 17(1):9-23.

Frost, L. 2001. 'Finding the top people', HR Future Magazine, 1(3):30-32.

Herman, R. E. \& Gioia, J. L. 2000. How to become an employer of choice. Winchester Virginia: Oakhill Press.

Johnson, M. 2000. Winning the people wars: Talent \& the battle for human capital. London: Prentice Hall.

Kennedy, S.H. 1977. 'Nurturing corporate images: Total communication or ego trip?' European Journal of Marketing, 11:120-164.

King, S. 1991. 'Brand building in the 1990s', Journal of Marketing Management, 7: 13.

Kinnear, L. \& Sutherland, M. 2000. 'Determinants of organisational commitment amongst knowledge workers', South African Journal of Business Management, 31(3):106112 .

Kotler, P. 1997. Marketing management. New Jersey: Prentice-Hall.

Leonard, D. 2000. 'They're coming to take you away', Fortune Magazine 141(11): 35-48.

Lopus, A.E. \& Murray, P. 2001. Washington CEO. [online] URL:

[http://www.waceo.com/archive/feb01/bestcompanies.html] (last accessed 14 June, 2001).
Ludlow, C. 1999. Employer branding: Fact or fiction? [Online] URL:

http://www.henrion.com/info/articles/employer html.

(accessed 6 September 2001).

Nel, P.A., Radel, F.E. \& Loubser, M. 1990. Researching the South African market. Pretoria: University of South Africa.

Paul, D. (Ed.). 2000. The best companies to work for in SA. ( $2^{\text {nd }}$ Edition). Cape Town: Zebra Press.

Rifkin, J. 2000. The end of work. London: Penguin Books.

Robbins, S. P. 1998. Organisational behaviour. $\left(8^{\text {th }}\right.$ Edition). New Jersey: Simon \& Schuster.

Schmidt, C. \& Ludlow, C. 1995. The quest for identity. London: Cassell.

Simons, S. 2000. 'Employer of choice checklist'. [online] URL:

http://www.seek.com.au/editorial/0-5-19 work culture htm (accessed 14 June 2000).

Sullivan, J. 1998. 'Becoming an employer of choice a lofty goal'. [online] URL:

http://ourworld.comuserve.com/homepages/gateway/pp15js 20.html. (accessed 5 July 2001).

Templer \& Cawsey, 1999. 'Rethinking career development in an era of portfolio careers', Career Development International, 4(2):70-76.

The Conference Board. 2001. 'Engaging employees through your brand - Preliminary findings'. [online].URL:

http://www.conference-

board.org/MembersOnly/members/pdf-files/RR-1288-ES.pdf (accessed 2 August 2001).

'The war for managerial talent'. 2001. Harvard Management Update Article. Product Number: U0103B.

Tulgan, B. 2001. Winning the talent wars. New York: W. W. Norton \& Company, Inc. 